\title{
LAVRA NO DESERTO A POÉTICA DE NUNO GUIMARÃES
}

\author{
Aline Duque Erthal \\ (Universidade Federal Fluminense)
}

\begin{abstract}
RESUMO
A resposta política à leitura e à vivência moderna do real deu-se de diversas maneiras na poesia portuguesa pós-60. Olhos contemporâneos voltam-se com crescente atenção para essas escritas, mas um nome permanece imerecidamente obscuro: o de Nuno Guimarães. Apesar da vida e produção curtas, o poeta erigiu uma obra em que se cruzam as principais linhas de reflexão dos anos 60 e tendências desenvolvidas na década de 70; ao mesmo tempo, sua voz autônoma e madura exibe envergadura suficiente para merecer um lugar ético e poético de interesse no panorama da literatura portuguesa.
\end{abstract}

PALAVRAS-CHAVE: Nuno Guimarães, poesia portuguesa contemporânea, deserto.

\begin{abstract}
The politic answer to modern reading and experiencing of the real was given in various ways in Portuguese poetry post-1960. Contemporaneous eyes are focusing with increasing attention those writings, but one name remains undeservedly obscure: Nuno Guimarães. Despite the short life and production, the poet erected a work that intersects the main lines of reflection of the 60's and trends that would be developed in the 70's; at the same time, he exhibits a voice wich is independent and mature enough to deserve an ethical and poetic place of interest in Portuguese literature panorama.
\end{abstract}

KEYWORDS: Nuno Guimarães, contemporary Portuguese poetry, desert. 


\title{
1. VACILAÇÕES: APROXIMAÇÃO E AFASTAMENTO, REALI- ZAÇÃO E EXPECTATIVA ${ }^{1}$
}

\author{
"Quem das rotas diverge e encaminha \\ seu canto por inábil dispersão" \\ Nuno Guimarães (1995, p.?)
}

Em Na senda da poesia, Ruy Belo se encanta com um poeta "muito exigente", "sem excrescências, sem exibicionismos, com uma grande economia" e simplicidade conquistada com um trabalho necessariamente árduo e inteligente (BELO, 2002, p. 334). Trata-se de Nuno Guimarães (1942-1973), que, em seus 31 anos de vida, publicou apenas dois livros - Corpo agrário (1970) e Os campos visuais (1973). Ambos só foram reeditados em 1995, em volume único organizado por Fernando Guimarães.

Apesar da produção curta, não é difícil encontrar textos críticos a respeito do poeta. Não que sejam muitos; mas foram escritos por nomes reconhecidos e constam em espaços importantes da nossa crítica atual. Joaquim Manuel Magalhães, Gastão Cruz, Cleonice Berardinelli, Fernando Pinto do Amaral e Fernando Martinho, além de Ruy Belo, são alguns dos nomes que lhe dedicam comentários, em publicações como os livros Os dois crepúsculos, O mosaico fluido, Na senda da poesia, A vida da poesia e a revista Colóquio Letras. As inserções ou são elogiosas (a maioria) ou neutras (quando Nuno Guimarães é citado em um panorama literário, por exemplo), e mesmo neste último caso é significativa a lembrança do autor. Frequentemente há o lamento por sua morte prematura, mas o reconhecimento de sua voz como "original" e "amadurecida" (CRUZ, 2008, p. 297) é maior do que a dúvida sobre os caminhos que o poeta seguiria e sua consequente capacidade ou não de figurar em um lugar de interesse no panorama da literatura portuguesa.

Destaquem-se, de início, dois desses comentários alheios a respeito da obra de Nuno Guimarães. Na recensão ao primeiro livro do poeta, o crítico Fernando Martinho enxergava dois campos principais de produção poética em fins dos anos 1960 - um, iniciado por Poesia 61, teria como polo de atração a "consciência linguística, o discurso tenso de Gastão Cruz" (MARTINHO, 1972, p. 77); neste grupo Martinho situava Nuno Guimarães. O outro campo seria o da "viragem", contestaria essa "via iniciada por Poesia 61", sendo marcado pela imaginação, o desregramento e o furor criativo, e seu ponto de partida seria "o lirismo apaixonado de Herberto Helder” (MARTINHO, 1972, p. 77). Já Cleonice Berardinelli, em texto de 1977 intitulado "A poesia portuguesa no século XX" (BERARDINELLI, 1977, p. 19-35), via em Nuno Guimarães um poeta de retomada do caminho da poesia experimental, trilhado na década anterior, como lembrava ela, por Herberto Helder e Antônio Aragão. ${ }^{2}$ 
Sob determinados pontos de vista, encontram-se ainda afinidades com Carlos de Oliveira (o campo semântico, uma secura em linguagem e imagética) ou com Fiama Hasse Pais Brandão; porém, como alerta Gastão Cruz em texto de $A$ vida da poesia, mesmo deles "não convém aproximá-lo demais. Porque, sendo visivelmente uma poesia de síntese, uma espécie de cruzamento das principais linhas de pesquisa poética dos anos 60 , a poesia de Nuno Guimarães, extremamente coesa, amadurecida e original, é uma criação autónoma de incontestável envergadura, apesar da sua reduzida extensão" (CRUZ, 2008, p. 297).

Importa não tanto classificar Nuno Guimarães, enquadrando-o em um ou outro grupo, aproximando-o excessivamente de um ou outro nome; mas observar como, a partir de uma observação estética e ética acurada de seu tempo, o poeta é capaz de - fazemos coro com Gastão Cruz - encontrar uma maneira própria de responder às questões da segunda metade do século XX: os horrores da Segunda Guerra Mundial e do Holocausto, a dessubjetivação do homem por regimes autoritários, o abalo de crenças e ideologias.

\title{
2. DO NEORREALISMO PARA NOVAS BUSCAS
}

\author{
"se queimadas a voz e a garganta \\ nenhuma forma ou cinza ainda perdura" \\ Fernando Guimarães (1995, p. 50)
}

Nas décadas de 40 e 50, o neorrealismo, com fundamentação marxista, esforçava-se por comunicar o mais claramente possível sua ideologia, privilegiando um sistema de representação facilmente decodificável pelo público leitor, com linguagem e imagens que lhe fossem familiares. $\mathrm{Na}$ década de 60, essa formulação de matriz ainda positivista foi posta em causa. A percepção de um esvaziamento do real e da problematização de qualquer transcendência, de que Ruy Belo é exemplar - "É muito triste andar por entre Deus ausente" (BELO, 2009, p. 162), "mesmo ao falar de deus eu me esqueço de deus" (BELO, 2009, p. 519), diz o poeta que pertencera à Opus Dei -, deu forma a escritas de solidão e distopia, que iriam se manifestar de diferentes maneiras nos autores dos anos 1960 e da década seguinte. A questão da referência em poesia deslocou-se da acepção ortodoxa do realismo estético (em que referencialidade e denotação se confundiam, pressupondo um "real" pré-discursivo e objetivo, a que a escrita remeteria) para a ideia de que referenciar poderia ser redescrever e, assim, reescrever (com o "real" tomado já como construção intersubjetiva). Essa crise da mimese tem raízes na revisitação ao Simbolismo e à tradição modernista, passando ainda pelas teorias do formalismo russo e do estruturalismo.

Ao não persistir na mesma relação de mundo do neorrealismo social, os poetas dos anos 60 e 70 distanciaram-se tanto de uma visão teleológica da história (e de sua suposição de fim utópico), quanto da possibilida- 
de da transparência (ou perfeita correspondência entre o dito e o dizer) da linguagem. O que não quer dizer, como observa Rosa Maria Martelo, ${ }^{3}$ que se desrealizou completamente o discurso. $\mathrm{O}$ texto não deixa de estar ligado à realidade - foi esta que se esvaziou, virtualizou, por conta da percepção de que o real é uma construção em permanente metamorfose e sujeita a pontos de vista variáveis. Essa percepção desmascara a eleição de um estado de realidade como mais "verdadeiro" do que outros, mostrando que qualquer dado real é apenas uma, entre tantas possíveis, ficção (ideologicamente) construída. Por conseguinte, o status de mais "realista" ou "referencial" conferido a qualquer discurso tem mais a ver com um "efeito de familiaridade relativamente aos padrões textuais utilizados do que com a existência efectiva de um grau superior de informação" (MARTELO, 1998, p. 32).

A relação transparente e imediata entre palavras e coisas passa a ser vista como uma ilusão perigosa. O risco é o de admitir qualquer coisa - uma ideologia, uma visão de mundo, um dizer - como transparente ou natural, e não como uma ficção parcial e construída. O que os de 60 e, mais tarde, de forma um pouco diferente - mais agravada, talvez - os de 70 fazem é desnudar esse real virtualizado.

A resposta poética à leitura e à vivência moderna do real (moderna no sentido de uma estética vinda de Baudelaire que, em 1960, se faz com uma retomada da tradição mais radical modernista e, em 1970, na reativação de uma forma mais lato da modernidade) $)^{4}$ deu-se de diversas maneiras em território português. Em Nuno Guimarães, mostra-se sob uma estratégia de não fixação engendrada por dois movimentos, à primeira vista, paradoxais: multiplicação e esvaziamento - que, na imagética do poeta, podem se representar pelo binômio lavra e deserto.

\section{3. (PA)LAVRA}

Desde o primeiro poema de Corpo agrário, percebe-se uma extrema atenção - declarada e exercida - à polivalência da palavra, construindo uma problematização constante de linguagem e referencialidade. Nuno consegue um "texto poético que é simultaneamente um texto crítico" a partir de um "classicismo que se põe em causa", na avaliação de Gastão Cruz (2008, p. 297). O rigoroso respeito à pontuação e ao uso de maiúsculas, a escolha frequente por composições clássicas (em especial, o soneto) são indícios desse cuidado; mas é sobre o significante que a lupa do poeta se detém de forma mais esmerada.

Um dos termos-chave a costurar os dois livros do poeta é lavrar (e outros signos do seu campo semântico, como arar, arado, agricultura, fruto, semear, ceifar, lavoura). Lavrar significa cultivar a terra. E, também, explorar uma jazida; bordar; cinzelar; corroer, sulcar. Seu substantivo mais diretamente correspondente, lavra, registra entre seus sentidos "qualquer lugar onde se cria e/ou produz algo; fábrica, fabricação" e "faculdade de criar, de conceber algo; autoria, elaboração, invenção". Trabalho, cultivo, exploração, corrosão, criação e fabricação formam uma nuvem que se con- 
densa a cada momento em que o significante lavra é convocado à poesia de Nuno Guimarães. Assim, versos como "filhos lavradores/ que se lavram a si na terra escassa" ganham diversas leituras possíveis: supondo que os filhos são homens (e mesmo isso o poema deixa em aberto), eles podem ser criadores ou (e) destruidores de si; com seu trabalho, se corroerem ou (e) se fabricarem, por exemplo.

A polissemia estende-se a outros signos, gerando um exercício combinatório na esfera semântica que põe em relação, de diversas formas, as palavras. A esse movimento acrescentam-se outros, sonoros e (orto) gráficos, com aliterações, assonâncias e rimas (perfeitas e imperfeitas, de fim de verso e internas), tornando ainda mais complexa a rede de aproximações possíveis e a consequente ambiguidade. Alguns exemplos escolhidos de dois poemas consecutivos, que parecem extensão um do outro por conterem diversos elementos de ligação, como palavras repetidas e a recorrência de sonoridades: " "Um magma amarado. E não amargo." (GUIMARÃES, 1995, p. 49) e "amargos amigos a morrer" (GUIMARÃES, 1995, p. 50); "artífice", "arte" e "ártica" (GUIMARÃES, 1995, p. 49); "despedida", "resumida"e "medida"; "amor" e "rumor" (GUIMARÃES, 1995, p. 49); "perdura" e "dura" (GUIMARÃES, 1995, p. 50); "consome" e "nome" (GUIMARÃES, 1995, p. 50); “fazer” e "morrer" (GUIMARÃES, 1995, p. 50); "antigos" e "amigos" (GUIMARÃES, 1995, p. 50), entre outros.

Com a ambiguidade conseguida pela polissemia e o jogo sonoro, Nuno Guimarães nos condiciona a perceber além dos significantes impressos. Onde lemos o verbo lavrar, somos motivados a pensar também em lavar: "A chuva lavrará sobre esta tábua/ a camisa. Um resto de palavras,/ as derradeiras sílabas no linho". Ainda nesses versos, observamos o jogo lavra/palavra, que se repete em outros momentos dessa poética. Como nos fragmentos:

\author{
Na boca tolhem água \\ os alimentos. Palavras \\ não são de mesa e desertam \\ dos rios e coisas férteis. \\ Nos corpos de lavradio \\ fazem poiso. [...] (GUIMARÃES, 1995, p. 24) \\ as palavras aprendem. Mães abertas \\ à aridez dos filhos lavradores \\ que se lavram a si na terra escassa (GUIMARÃES, 1995, p. 27) \\ Dobadoira que lavras a secura \\ do corpo de erosão. Que sem palavras \\ emigra a sua morte sobre a cama. (GUIMARÃES, 1995, p. 39)
}

Um signo a mais, portanto, evola-se rumo à nuvem de que falamos anteriormente: passamos a pensar também na $p a(+)$ lavra: lavor, cultivo e exploração, criação e corrosão da linguagem. Se Nuno Guimarães nos 
leva a ler as palavras com atenção redobrada, fazendo do significante um leque de relações de proximidade até então insuspeitas, ${ }^{8}$ o poeta alarga a percepção também para a multiplicidade dos signos em seu funcionamento relacional. Assim, a palavra pode assumir significados vários em função dos outros signos (cada um desses outros signos, por sua vez, desdobrando sua própria versatilidade).

Essa prática do múltiplo, exercício de liberdade na linguagem, é também busca por uma experiência mais livre de mundo e de subjetividade. Esquivando-se do panfletarismo, Herberto Helder, Ruy Belo, Nuno Guimarães, os de Poesia 61 (e tantos outros) procuravam responder po-eticamente à condição desintegrada do real, ${ }^{9}$ não pelo fechamento do poema em si mesmo (de que foram acusados alguns), mas por uma escrita desse esvaziamento na espessura do poema. Se a experiência de mundo é descentrada, errática, fragmentária, a experiência do (no) texto também o será. Em seu primeiro poema de Poesia 61, Fiama Hasse Pais Brandão escreve:

\section{grafia 1}

Água significa ave

se

a sílaba é uma pedra álgida

sobre o equilíbrio dos olhos

se

as palavras são densas de sangue

e despem objectos

se

o tamanho deste vento é triângulo na água

o tamanho da ave é rio demorado

onde

as mãos derrubam arestas

a palavra principia (BRANDÃO, 1961, p. 1, grifos nossos)

Todo o poema é desestabilizado pela partícula se, multiplicando possibilidades e inaugurando um espaço onde mesmo a água pode significar ave. Reivindica-se a novidade da palavra poética, que se configura como "a violação, o afastamento em relação a uma norma que é a linguagem usada nas relações habituais entre os homens” (BELO, 2002, p. 101). É onde se instaura uma queda que "a palavra principia".

Fiama derruba, Nuno Guimarães rói arestas. Primeiro poema de Corpo agrário:

Palavras que rebentam. Aflorando

a pedra, a solidão, deslizam, vagas, 
gramaticais, roendo inconformadas

as arestas, $\mathrm{o}$ atrito, puras. Quando

nos líquidos, no éter, na distância,

diluem-se e morrem acabadas.

Não nos corpos, nas rugas, nas arcadas:

combatem, rumorosas, cal e cântico.

É difícil atarem corpo e vida

aos que vivem e morrem subjacentes

subjazendo, talhados para mina.

Mas despertadas, bem ou mal medidas, rebentam em ogiva, funcionais

chamas supostamente adormecidas.

(GUIMARÃES, 1995, p. 23, grifos nossos)

As palavras rebentam, despertam, roendo inconformadas bordas de significação. O poema se tece como espaço de (valho-me, novamente, da expressão usada por Silvina Rodrigues Lopes, em A estranheza-em-comum) "vacilação - aproximação e afastamento, realização e expectativa" (LOPES, 2012, p. 11).$^{10}$ Assim, os diferentes significados possíveis de palavras como "arcadas" (arco arquitetônico/determinada disposição óssea/movimento do arco em instrumento musical de cordas), "mina" (nascente/depósito subterrâneo/armadilha de guerra) e "ogiva" (artefato bélico/cruzamento de duas curvas no topo de construção arquitetônica) são movimentados por e acionam $a$ vitalidade plurissemântica de outros signos, em permanente alteração mútua. A tabela destaca alguns dos significados que determinadas palavras podem assumir dependendo das combinações operadas:

\begin{tabular}{|c|c|c|}
\hline SIGNO & $\begin{array}{c}\text { CAMPO } \\
\text { SEMÂNTICO }\end{array}$ & $\begin{array}{c}\text { RELAÇÕES COM OUTROS } \\
\text { SIGNOS DO POEMA }\end{array}$ \\
\hline \multirow{2}{*}{ Arcadas } & Arquitetura & Anatomia \\
& Música & corpos, rugas \\
Mina & Mêntico
\end{tabular}


A rebentação das palavras é, portanto, enunciada e operada; o poema abrange e intercambia diversas combinações possíveis de significados. Adapto o que Silvina Rodrigues Lopes escreve sobre a relação entre o pensamento da literatura e as obras ao cosmo menor da relação entre o poema e os signos: o poema ${ }^{11}$ é "invenção de linguagens, desterritorialização", acolhimento da "estranheza" das palavras e das coisas ${ }^{12}$ e proposição de relações que incitem a "apropriação da des-apropriação que as constitui, 'apropriação' antropofágica ou criadora para a qual a ilegibilidade não se opõe ao legível, pois, pelo contrário, suporta o infinito da leitura" (LOPES, 2012, p. 13).

Desapropriação e reapropriação antropofágica: desterritorialização de termos, que se reterritorializam em circulações mútuas de intensidades. ${ }^{13} \mathrm{Ou}$, como assinala Ruy Belo, o poeta dá às palavras "novas ligações e é como se as fizesse esquecer a casa dos pais":

Aí temos uma palavra novinha em folha, livre, isenta ainda de qualquer servidão, próxima da fonte, com o seu peso, a sua densidade, o seu volume, a inaugurar um espaço que só pode ser poético. Como isto é possível? É que cada palavra é um infinito e exerce sobre nós o sortilégio que o seu poder mágico lhe permite. (BELO, 2002, p. 83)

De uma maneira muito própria, Nuno Guimarães expõe as costuras da linguagem, revelando em conexão com quais outras as palavras fazem ou não passar intensidades, em que multiplicidades elas introduzem e metamorfoseiam as suas, com que corpos sem órgãos elas fazem convergir os seus. As combinações manipuladas pelo poeta (e realizadas/ transformadas pelo leitor) desestabilizam cenários e turvam sentidos; seu ludismo, porém, não resulta em derramamento textual ou afrouxamento de linguagem. Ao contrário: o que há é concentração extrema no significante; poemas curtos; estrutura muitas vezes rígida. Uma "gravidade medida/ algébrica, em fogo lento." (GUIMARÃES, 1995, p. 43). Mas talvez o melhor verbo não seja concentrar - no dicionário, "fazer convergir ou convergir (o disperso ou separado) para (um centro ou ponto)"14. Antes saturar - e saturar nas arestas:

Doença de palavras com morfina sobre o peito que seca e envelhece (as palavras as pedras como doem)

um peso em cada peito deserto cado vez mais na raiz. Não é bem a secura de palavras mas a secura de aves. Perigoso estio que, pesando sobre as asas, lhes fere o voo livre.

Aves de seca. Anos que se queimam noutro passe, outra morte, outra incerteza outro repouso algébrico dos membros. 
Nem a margem dos rios se acomoda

ao rumor geométrico do fogo

às formas aos sinais - o sedimento

onde as noites e o sono se acumulam

as areias, a fome, o movimento,

o corpo saturado nas arestas.

(GUIMARÃES, 1995, p. 25, grifos nossos)

O poema traz um trabalho com os fonemas /p/ e /d/ que se mostra recorrente em outros textos de Nuno Guimarães. Os sons caem como pancadas, pedras/palavras que pesam. A eles, acrescentam-se marcadamente os fonemas $/ \mathrm{k} / \mathrm{e} / \mathrm{q} /$, levando para o estrato sonoro a estiagem do peito que, diz-nos o poema, seca e envelhece. E não apenas ele: estio, seca, areias, fome ligam-se também à paisagem (as aves, a margem dos rios) e ao tempo ("anos que se queimam" em morte, incerteza). Os sedimentos dessa queima, quase lixiviação de corpos e paisagens, acumulam-se nas arestas da linguagem: as "formas", os "sinais". A linguagem enquanto sistema de signos (significante + significado) é, portanto - tal como corpo e paisagem -, desertificada no centro, em sua raiz (cito outros versos: "Nada lhes arde por dentro./ Pela sua condição/ difícil, são sinais secos" [GUIMARÃES, 1995, p. 24]). É nas arestas que Nuno sedimenta sua poesia, explorando ao máximo os sinais ${ }^{15}$ enquanto forma gráfica ou sonora; é partir deles, desses pequenos ângulos que são os grafemas e os fonemas, que se pode criar toda a diferença e multiplicidade. Aí que "se vive/ adestrando os sentidos [atenção ao plural] e a morte " (GUIMARÃES, 1995, p. 26).

O efeito de desertificação da linguagem, ou esvaziamento de sentido do texto (sentido como orientação unívoca), é reforçado pelo também frequente recurso às listagens, colecionando imagens a tal ponto que a percepção não é mais capaz de alcançar uma organização total e estabilizada. No poema em questão, são listados: "as palavras as pedras"; "outro passe, outra morte, outra incerteza/ outro repouso algébrico dos membros"; "rumor geométrico do fogo", "formas", "sinais"; noites, sono, areias, fome, movimento, corpo.

\section{4. "MOVEU PELO DESERTO/ O SER NAVEGADOR"}

Falávamos que lavra, com outros signos de seu campo semântico direto, é uma das linhas de força nessa poética. A esse microuniverso acrescenta-se outro, que já vem se insinuando nesta análise: o do deserto, com sua constelação de imagens (secura, areia, estio), perpassando os dois livros de Nuno Guimarães e inserindo-os em uma paisagem que se revela bastante significativa no panorama da literatura portuguesa do século XX: a de espaços áridos, não raro associados à errância, ao vazio, a ausências. Lembramos uma observação feita por Carlos de Oliveira em O aprendiz de feiticeiro: 
A poesia portuguesa, sobretudo a moderna, está cheia de desertos. Deserto é uma palavra chave, uma obsessão, como podia provar facilmente. Mas descansem. Limito-me a propor a seguinte identidade mais ou menos algébrica:

floresta $=$ labirinto

labirinto $=$ deserto

deserto $=$ floresta

Quod erat demonstrandum. (OLIVEIRA, 1973, p. 202) ${ }^{16}$

A eleição do deserto como "palavra-chave" da poesia moderna é interessante (décadas antes, já o heterônimo Álvaro de Campos escrevia: “Grandes são os desertos, e tudo é deserto" [PESSOA, 1999, p. 184]). ${ }^{17} \mathrm{De}$ fato, a paisagem desértica com frequência aparece como figuração de um além (não no sentido transcendental, mas no de outro espaço/tempo) do conhecido ou habitual. Em poetas como Herberto Helder, Helder Macedo, João Miguel Fernandes Jorge, Al Berto, António Ramos Rosa e Luís Miguel Nava, o deserto é chamado ao texto como indagação de realidade, sujeito e palavra poética, sob a forma de: metáfora para a página em branco; deserção, desejada pela poesia, de usos e sentidos convencionais; denúncia do vazio ético em uma determinada situação política ou acusação do esvaziamento de sentido da vida moderna; manifestação da aridez das relações afetivas ou a fragmentação do sujeito e a rarefação de subjetividades; ausência de respostas (transcendentais ou não) para as questões da modernidade; desabitação causada pela perda - da infância, dos mitos, da esperança em si, no homem e nos deuses.

Em Nuno Guimarães, o esvaziamento da história e do real e a inexistência de algo ou alguém que possa se colocar no lugar da resposta é excesso de possibilidades; múltiplos sem um (penso em Deleuze e, novamente com alguma liberdade, em Silvina Rodrigues Lopes). ${ }^{18}$ Esse deserto excessivo se perfaz com poemas enxutos, porém plurissignificativos. Voltamos a um texto do qual já citamos uma das estrofes: "Subalimentação":

Desertas. De pouco fogo.

Nada lhes arde por dentro.

Pela sua condição

difícil, são sinais secos.

Na boca tolhem água

os alimentos. Palavras

não são de mesa e desertam

dos rios e coisas férteis.

Nos corpos de lavradio

fazem poiso. E contam deles

o pouco fogo. O deserto

que os habita no centro. 
Ausência de limo ou saga

de peito fraco, sem poços.

Ávidos de chuva ou terra

os fonemas arenosos.

(GUIMARÃES, 1995, p. 24)

O poema contrapõe, nos corpos de lavradio, a sua imagem mais óbvia e imediata - a do campo para agricultura, associado à fertilidade e cuja exploração consiste em preenchimento com plantas, habitação - ao deserto, esvaziamento, que pode trazer o outro significado possível de corpo de lavradio: o terreno de mineração, cuja exploração consiste em extração, retirada de matérias das rochas, desnudamento. Nesse sentido, o corpo de lavradio é a própria linguagem em Nuno Guimarães: o poeta deserta de e desertifica o previsível, o imediatamente reconhecível. Ao hiperalimentar a linguagem com a plurissignificação dos signos, ele também a subalimenta, esvaziando as palavras de significados em si. Os sinais impressos no papel, "secos", habitados em seu centro por um deserto ("peito fraco", "peito seco", [GUIMARÃES, 1995, p. 25]), são “fonemas arenosos”, ávidos de significações que só podem se dar nas arestas, pontas/pontos de contato. Deserção que se dá em outras esferas: a poesia de Nuno Guimarães mantém certa convencionalidade formal para pôr em causa essa própria estrutura, reivindicando um novo dizer. O mesmo acontece com a conservação de alguma ligação com real. As "coisas perfeitas e imóveis" são chamadas ao poema para serem questionadas, desestabilizadas; há "mobílias/ inexactas à vista - todo o real/ oscila no seu leito" (GUIMARÃES, 1995, p. 83).

A prática e enunciação de uma multiplicidade de desertos-em-relação (infinitamente variada e, ao mesmo tempo, irredutível a qualquer de suas facetas ou ângulos) ${ }^{19}$ na linguagem integra o esvaziamento de uma acepção unificadora de real e o reconhecimento do que há de plural e móvel nele. Não há, portanto, descolamento em relação à realidade, mas a experiência ética desta no texto: o livro é "O extremo/ deserto" (GUIMARÃES, 1995, p. 82). A tentativa de apreensão rigorosa de um mundo dúbio e desagregado passa por uma linguagem dúbia e desagregada. E, especialmente nos primeiros poemas de Campos visuais, a própria visualidade do texto se inscreve como modelo da fragmentação e flutuação da realidade: com a escansão silábica de palavras, fendendo-as e conferindo-lhes sentidos ambíguos, a materialidade da linguagem exemplifica um mundo em que inexiste perfeita e indiscutível coesão. Como no poema a seguir, que traz abandonos e criações, e cruzamentos transfiguradores de referências como San Juan de la Cruz, Sá de Miranda, Antígona, Camões e Fernando Pessoa. O texto se escreve como ocupação deslocada - "pelo deserto/ o ser navegador" - e em deslocamento: 
I

De que te vestes, corpo

a bando nado

da luz no teu país. De que te cobres?

Esquecido da água e sem

leitura. De que lado

passarás a viver

(ou, transigindo,

de que lado

passarás a morrer, a clarear)?

II

Em que sarça em que lavoura

recomeças noche oscura

Amada em el Amado transformada

Juan de S. Juan alterado a nomear

la Cruz as coisas todas elas alteradas.

De que modo assim

se ateiam se semeiam

de que modo perecem na cabeça?

III

El rostro recliné sobre el

Amado e desertou

Juan de i. e. moveu pelo deserto

la Cruz o ser navegador

de corpos e de dunas

(perito e estratega

em aves migratórias).

IV

Pensá-Lo é destruí-

-Lo. Por isso O pensa.

Juan de Residual, $\mathrm{O}$ ama.

la Cruz Mas em que osmose ou

canto subvertido?

Em que deserto ou

caos O organiza? (GUIMARÃES, 1995, pp. 57-58)

"Pensar é destruir. O próprio processo do pensamento o indica para o mesmo pensamento, porque pensar é decompor". As palavras de Bernardo Soares (PESSOA, 2006, p. 200) ressoam em Nuno Guimarães, que nos convida a pensar a linguagem, destruí-la, decompondo referências do cânone literário e palavras - como o poeta faz em "a bando nado" e em outros momentos, como: "Amando nada abando-/nado", "Levita a dor", "a mar", "Pastor-/eia a rês", "Res publica", "Hás-de rio Hades", "dupli-/cidade”, "rigor-/ossos". Ser “Fomen-/tador da divisão.", desertar do conhecido 
e navegar no deserto. A exploração da iconicidade do poema e seus deslocamentos sonoros, tomando-o como "espaço de resistência ao hábito, à ordem, ao senso-comum", como observa Rosa Maria Martelo, é, de resto, traço recorrente nos poetas que publicaram nos anos 60:

Nesta perspectiva, visão e audição (como imagens, na escrita) estariam diretamente ligadas à crise modernista da representação e implicariam a dimensão meta-reflexiva desenvolvida pelos Modernismos e enfatizada pelas poéticas de 60 . Construídas sobre a sugestão do sensível, mas acontecendo no limite da linguagem, as imagens (em seu sentido retórico, mas também na sua ambição de visão e de forma) trabalhariam sobre a falência dos sentidos. [...]

Percebemos assim melhor, talvez, que a imagem surja nos poetas dos anos 60 como uma figura retórica, associada à metáfora, e como um entendimento da escrita que convoca a visão e a audição a um nível que nada tem a ver com a écfrase ou com a exploração do reconhecimento do mundo habitual por parte do leitor. Trabalhar na fronteira do sentido (significância), usando aquilo que é o fundo de visão que existe no texto, é sempre um acontecimento libertário (a partilhar com o leitor). Daí a formulação do poema como espaço, "lugar" (Herberto Helder) ou "área branca" (Fiama), um espaço de resistência ao hábito, à ordem, ao senso-comum, o que pode envolver dimensões políticas (a rejeição da Guerra Colonial e do fascismo, como acontece em Fiama e Gastão Cruz; a revisitação irônica do campo e da cidade, em Armando Silva Carvalho; a recusa das políticas de género conservadoras, violentamente postas em causa por Neto Jorge e Maria Teresa Horta, etc....). (MARTELO, 2012, p. 21)

O texto se faz precariedade exemplar da precariedade do mundo. Por isso é múltiplo, deserto, fendido. Produz-se um modelo do mundo, mas este já não poderia ser o de uma perspectiva neorrealista. Se o texto se enuncia como amostra, o é de um mundo oscilante; e, portanto, o pouco que a poesia pode afirmar é a dúvida, a renúncia ao habitual. $\mathrm{O}$ corpo e a experiência do escrever em erosão são metáfora e metonímia de um mundo já não tão claro - transparente, poderíamos retomar. É nesse sentido que podemos pensar também o acúmulo, em um mesmo poema, de referências que não se articulam entre si. Especialmente os textos do segundo livro de Nuno Guimarães são exemplares desse procedimento: escrevem-se "elementos" ${ }^{20}$ que parecem compor um quadro referencial minimamente reconhecível; quando o leitor já espera alcançar alguma segurança, porém, outros elementos (de campos semânticos e/ou aspectos fônicos distintos, por exemplo) atravessam a leitura e o poema encontra-se novamente em um vazio - o deserto. A sintaxe, a conjugar fragmentos de cuja articulação jamais se consegue recuperar um todo, deixa-nos restos, grãos de areia que são soprados de um texto para outro, de forma provocantemente dispersiva, incitando o leitor a procurar identificar um ou outro elemento que funcione como um farol para os restantes, avançando e retrocedendo: 
Da água à terra, ao corpo, à luz, os elementos de uma experiência

e uma erosão ininterruptas. Sobre o movimento e a desordem, em que tudo repousa, um exercício rigoroso: o dúbio olhar.

II

Violenta e lenta, é a experiência. Não

voltarás ao campo das hipóteses. A tua vida avança e retrocede. Os sentidos são amplos, mas precisos. Quererás defender a claridade: mas é clara a chuva do teu cérebro, já tão experimental e experiente? São claros os caminhos em que tu, tudo se refaz e o caos é-nos a via, a mais segura?

$[\ldots]$

IV

Hoje, pouco afirma. O que era firme e sustentável - a cafeína, os hábitos, tropismos do corpo para a luz - foi já revisto num hábil processo de renúncia. O que era firme interroga, obscurece. Duvidosas são todas as colunas. (GUIMARÃES, 1995, p. 67)

Molduras (GUIMARÃES, 1995, p. 65) e diafragma (GUIMARÃES, 1995, p. 81) ambíguos, o "dúbio olhar" (GUIMARÃES, 1995, p. 66) do "variável/ e curvo cristalino" (GUIMARÃES, 1995, p. 67) deslocam-se em um exercício rigoroso do olhar e de erosão de linguagem; "violenta e lenta experiência”. A poesia de Nuno Guimarães, embora fortemente visual, em momento algum de seus dois livros é indicativa ou descritiva de uma realidade familiar (i.e. versões de mundo reconhecíveis). A "Geometria,/ a das imagens," é "turva” (GUIMARÃES, 1995, p. 81). E não poderia ser de outra forma: como ele poderia "defender a claridade", se já é tão posta em dúvida a mesma claridade da "chuva/ do teu cérebro"? Se "O que era firme/ e sustentável" foi revisto e "interroga, obscurece"? ${ }^{21}$ Experimental e experiente são já o homem, o poeta e a poesia. Depois "da perfeição perdida" e depois que "Os deuses cegos/ perderam o seu brilho, sobre as águas. Rodeiam/ a pupila, cansada pelo sol, enfraquecida/ pela acção dos nervos e das vagas" (GUIMARÃES, 1995, p. 74) -, "nada aqui, embora estável,/ nos redime do fim e do excesso,/ viáveis à demência” (GUIMARÃES, 1995, 74).

Na paisagem, como na linguagem, cada quadro é múltiplo em si (se o sujeito é dividido e fomentador da divisão, ele tem vários pontos de vista) e em função de outros quadros (como cada palavra é múltipla em si e em função das outras). Movimentar no poema essa multiplicidade intrínseca e relacional - "ambíguas mol-/duras" (GUIMARÃES, 1995, p. 65) - é colocar um Disco de Newton em rotação. Quando o disco gira, é como 
se as cores desertassem de si. Como acontece com esses pedaços de cor, o movimento perceptivo esvazia cada um dos quadros de uma paisagem, cada um dos signos da linguagem, que, em um "gasto perceptivo" (GUIMARÃES, 1995, p. 82), gera (gira) um novo - o branco. Deserto resultante de falta de certezas, ou, dizendo de outro modo, de excesso de possibilidades e movimento. Desertar: abandonar, sair de (mover-se para outro lugar). E também: fazer, criar deserto. Se desertamos de uma linguagem (poderíamos também dizer corpo, país, paisagem, subjetividade) conhecida, estabilizada, nos movemos em direção a outro lugar - outro "passe", "outra morte", "outra incerteza", outro "repouso algébrico dos membros". O deserto é representação possível, por conseguinte, tanto para as questões colocadas e para o espaço a ser refutado, quanto para a busca de suas respostas, o espaço de potência e criação.

A esta altura, cabe uma pergunta que suscitou o início de nosso percurso: qual é o lugar de Nuno Guimarães na poesia portuguesa pós-60? Fernando Martinho, na já mencionada recensão crítica ao primeiro livro do poeta, questionava se ele abriria "novas perspectivas ao lirismo praticado nos anos 60" ou seria ainda "o prolongamento de um dos caminhos" evidenciados na década anterior (MARTINHO, 1972, p. 77). Mas, já na recensão crítica ao segundo livro, o crítico reconhecia uma "autonomização de processos e temas":

Se a presença de Gastão Cruz ainda pode notar-se em Os Campos Visuais, é já de forma muito mais tênue, sem a tonalidade tutelar que assumia em Corpo Agrário. Nota-se, com efeito, no volume agora publicado [...] a justa medida duma vocação poética, que reunia as condições necessárias para constituir uma alternativa válida no leque de possibilidades que se oferecem a uma evolução equilibrada e sem clivagens gratuitas da poesia nacional. A morte, se interrompeu uma trajectória promissora, não bloqueou, no entanto, a ressonância duma voz poderosa, lição de rigor a que não falta a força interior e irreprimível do daimon, sem a qual a poesia corre sempre o risco de se transformar num exercício de linguagem sem referências, desenraizado (MARTINHO, 1974, p. 84).

Nuno Guimarães surge-nos como uma poética rigorosa coerente em sua multiplicidade, nos "campos" estético, imagético, subjetivo. O poeta decide-se pela indecidibilidade, pela não aceitação de relações interpretativas ou referenciais unívocas. Há em seus versos experimentalismo de linguagem, vizinhanças com o neorrealismo, contenção e tensão poéticas, certo subjetivismo, uma condição moderna no fazer poesia. Parece-nos, portanto, que Nuno Guimarães faz com as tendências poéticas de seu tempo o mesmo que opera no nível das palavras: coloca-as em contato, e dessas estranhezas postas no em-comum da poesia cria um novo (seu próprio) deserto, em habilíssima dispersão. 


\section{REFERÊNCIAS BIBLIOGRÁFICAS}

BELO, Ruy. Na senda da poesia. Lisboa: Assírio \& Alvim, 2002.

Todos os poemas. Lisboa: Assírio \& Alvim, 2009.

BERARDINELLI, Cleonice. A poesia portuguesa no século XX. Revista Letras, n. 26, 1977.

BRANDÃO, Fiama Hasse Pais. Morfismos. In: Poesia 61. Faro: edição dos autores, 1961.

CARVALHO, Gil de. Recensão crítica a Poesias Completas, de Nuno Guimarães. Revista Colóquio/Letras. Recensões Críticas, n. 147/148, p. 338, Jan. 1998.

CRUZ, Gastão. A vida da poesia. Lisboa: Assírio \& Alvim, 2008.

DELEUZE, Gilles; GUATTARI, Félix. Mil platôs: capitalismo e esquizofrenia 2, v. 1. São Paulo: Ed. 34, 2011.

GUIMARÃES, Nuno. Poesias completas. Org. e prefácio de Fernando Guimarães. Porto: Edições Afrontamento, 1995.

LOPES, Silvina Rodrigues. A estranheza-em-comum. São Paulo: Lumme Editor, 2012.

MACEDO, Helder. O deserto. In: MELO E CASTRO, E. M.. O próprio poético. São Paulo: Quíron, 1973.

MAGALHÃES, Joaquim Manuel. Os dois crepúsculos: sobre poesia portuguesa actual e outras crônicas. Lisboa: A regra do jogo, 1981.

MARTELO, Rosa Maria. Carlos de Oliveira e a referência em poesia. Porto: Campo das Letras, 1998.

. "De imagem em imagem". Revista Abril. Niterói: NEPA/UFF, vol. 5, n. 9, novembro de 2012 .

- Vidro do mesmo vidro: Tensões e deslocamentos na poesia portuguesa depois de 1961. Porto: Campo das Letras, 2007.

MARTINHO, Fernando J. B. Recensão crítica a Corpo Agrário, de Nuno Guimarães; "Do Agregado Sentimental", de António Torrado. Revista Colóquio/Letras. Recensões Críticas, n. 6, p. 77-78, Mar. 1972.

. Recensão crítica a "Os Campos Visuais", de Nuno Guimarães. Revista Colóquio/Letras. Recensões Críticas, n. 17, p. 84, 1974.

OLIVEIRA, Carlos de. O aprendiz de feiticeiro. Lisboa: Seara Nova, 1973. . Trabalho poético. Lisboa: Assírio \& Alvim, 2003.

PESSOA, Fernando. Livro do Desassossego. Org. Richard Zenith. São Paulo: Companhia das Letras, 2006. 1999.

. Poemas de Álvaro de Campos. Rio de Janeiro: Nova Fronteira, 


\section{NOTAS}

1 Expressão adaptada de Silvina Rodrigues Lopes (LOPES, 2012, p. 11).

2 É frequente, a título esquemático, as principais linhas estéticas da década de 60 serem divididas entre os de Poesia 61 (e nomes a eles ligados) e a Poesia Experimental, ainda que tenha havido poetas que mais ou menos mesclam ou ora se afastam ora se aproximam de cada um desses "setores". A década de 70 traria a "ultrapassagem" desses dois movimentos, com novos critérios e processos, adotados e empreendidos algumas vezes por poetas que já publicavam em 60 e propunham uma "evolução das próprias obras" (valho-me de expressões usadas por Joaquim Manuel Magalhães no ensaio "Alguns aspectos dos últimos anos", do livro Os dois crepúsculos [MAGALHÃES, 1981, pp 251-276]).

3 Refiro-me ao livro originado da Tese de Doutorado defendida por Martelo em 1996. No texto, a autora aborda a reformulação da noção de referencialidade no texto literário, desvinculando-a da denotação. Cf MARTELO, Rosa Maria. Carlos de Oliveira e a referência em poesia. Porto: Campo das Letras, 1998.

4 Cf: MARTELO, 2007, pp. 40-41.

5 Definições do dicionário Houaiss.

6 A coesão entre os textos dos dois livros de Nuno Guimarães é notável, com diversos casos em que um poema insinua ou introduz uma imagem ou processo sonoro que será desenvolvido nos seguintes. Enreda-se uma teia orientada para diversas direções, cada um de seus raios constituindo novas teias, em um emaranhado ao mesmo tempo dispersivo e extremamente coeso.

7 No mesmo poema, vemos ainda a abertura de lavra para outra possibilidade - lava: "Que lava ou que vulcão esta lavoura / nos lábios e nos ouvidos nos aquece" (GUIMARÃES, 1995, p. 40).

8 Já se percebe a proximidade - frequente de poema a poema - entre lavra e secura. Por ora, guardemos esse estranhamento, que será retomado adiante.

9 "O céu real é talvez irreal. Nada me garante que não contemplo um universo morto, um deserto. Talvez a máquina de facto parasse. Mas trabalha ainda nos meus olhos. Tece neles a sua própria harmonia." (OLIVEIRA, 1973, p. 282).

10 Transcrevo, ainda, o fragmento imediatamente anterior ao destacado: "A composição da obra literária é geradora de significações, desde logo devido ao simples facto de ser feita com palavras e por isso desencadear, no pôr-em-relação de sons, imagens e significados, processos de associação que apresentam semelhanças e dissemelhanças. Porém, ela não é por esse facto construtora de um sentido, individual ou colectivo, do mundo: as diversas significações são irredutíveis, não só entre si, como a qualquer instância exterior (referentes, ideias), sendo a sua pluralidade afectada pelo espaço-tempo indeterminado em que se inscrevem, disseminam. No desfazer de estereótipos ou fórmulas fixas, o dirigir-se ao outro põe em movimento uma memória trans-individual, um pensamento que se ergue sobre o "luto originário", o de tudo ter desde sempre desaparecido na palavra que o nomeou." (LOPES, 2012, p. 11).

11 "pensamento da literatura", no original.

12 "obras", no original.

13Cf DELEUZE; GUATTARI, 2011.

14 Primeira definição do Houaiss.

15 É interessante levar em consideração outras acepções de "sinal" dicionarizadas pelo Houaiss: vestígio/rastro e indício de um futuro. Cada poema carrega traços do anterior ("resto de palavras/derradeiras sílabas no linho" [GUIMARÃES, 1995, p. 40]) e também indícios do próximo (“Um fruto solar anunciado/ numa operária que trabalha no amor." e "Um fruto, um claustro anunciado/ num corpo operário em combustão." [ GUIMARÃES, 1995, p. 47]), configurando sempre passagens. Mais uma vez, não há concentração, mas centrifugação: circulação de sons, palavras e imagens e, a partir desse movimento, afastamento em relação a qualquer centro temático ou ideológico. 
16 Cenários áridos são, por sinal, sabidamente marcantes na produção de Carlos de Oliveira, sobretudo em livros como Uma abelha na chuva, Casa na duna e Finisterra.

17 Poema publicado originalmente em 1930.

18 A reflexão de Silvina Rodrigues Lopes que me ocorre é: "em qualquer obra literária visionária, elíptica, orientada para o conhecimento, para o humor ou para o trágico - sobra sempre o que a torna incompleta, uma intensidade que lhe desfaz os limites e a expõe como apresentação impossível de infinito. Daí, do facto de a sua incompletude não ser falta, mas excesso enquanto exceção sem regra ou lei que a identifique, nasce uma injunção paradoxal: feita na linguagem comum, ela não se dirige ao que está ou ao que passou, mas ao que passa: ninguém, nenhuma instituição, se pode colocar no lugar da resposta" (LOPES, 2012, pp. 11-12) [grifos meus].

19 Em Mil platôs, Gilles Deleuze e Félix Guattari descrevem dois tipos de livro: o livro-raiz, que supostamente "imita o mundo, como a arte, a natureza". A lei desse livro seria "a da reflexão, o Uno que se torna dois". "Cada vez que encontramos essa fórmula, [...] encontramo-nos diante do pensamento mais clássico e o mais refletido, o mais velho, o mais cansado", criticam os autores. O segundo tipo, o livro-radícula, do qual "nossa modernidade se vale de bom grado", aproxima-se mais do trabalho poético com que temos nos deparado: nele, "[...] a unidade não para de ser contrariada e impedida no objeto, enquanto que um novo tipo de unidade triunfa no sujeito. $\mathrm{O}$ mundo perdeu seu pivô, o sujeito não pode nem mesmo mais fazer dicotomia, mas acede a uma mais alta unidade, de ambivalência ou de sobredeterminação, numa dimensão sempre suplementar àquela de seu objeto. $\mathrm{O}$ mundo deveio caos, mas o livro permanece sendo imagem do mundo, caosmo-radícula, em vez de cosmo-raiz. Estranha mistificação, esta do livro, que é tanto mais total quanto mais fragmentada. O livro como imagem do mundo é de toda maneira uma ideia insípida. Na verdade não basta dizer Viva o múltiplo, grito de resto difícil de emitir. Nenhuma habilidade tipográfica, lexical ou mesmo sintática será suficiente para fazê-lo ouvir. É preciso fazer o múltiplo, não acrescentando sempre uma dimensão superior, mas, ao contrário [...] sempre n-1 (é somente assim que o uno faz parte do múltiplo, estando sempre subtraído dele). Subtrair o único da multiplicidade a ser constituída; escrever a n-1." (DELEUZE; GUATTARI, 2011, p 19-21).

20 Termo usado pelo poeta nos versos subsequentes e que diz respeito tanto a unidades linguísticas, quanto a constituintes químicos - e é justamente algo como uma experiência de química da linguagem o que se propõe.

21 Esse questionamento frontal (intensificado pelo recurso da segunda pessoa do singular e interrogações, como que exigindo resposta) de qualquer estabilidade, do real e da forma como o homem se relaciona com ele é recorrente no poeta. Destaco outros versos:

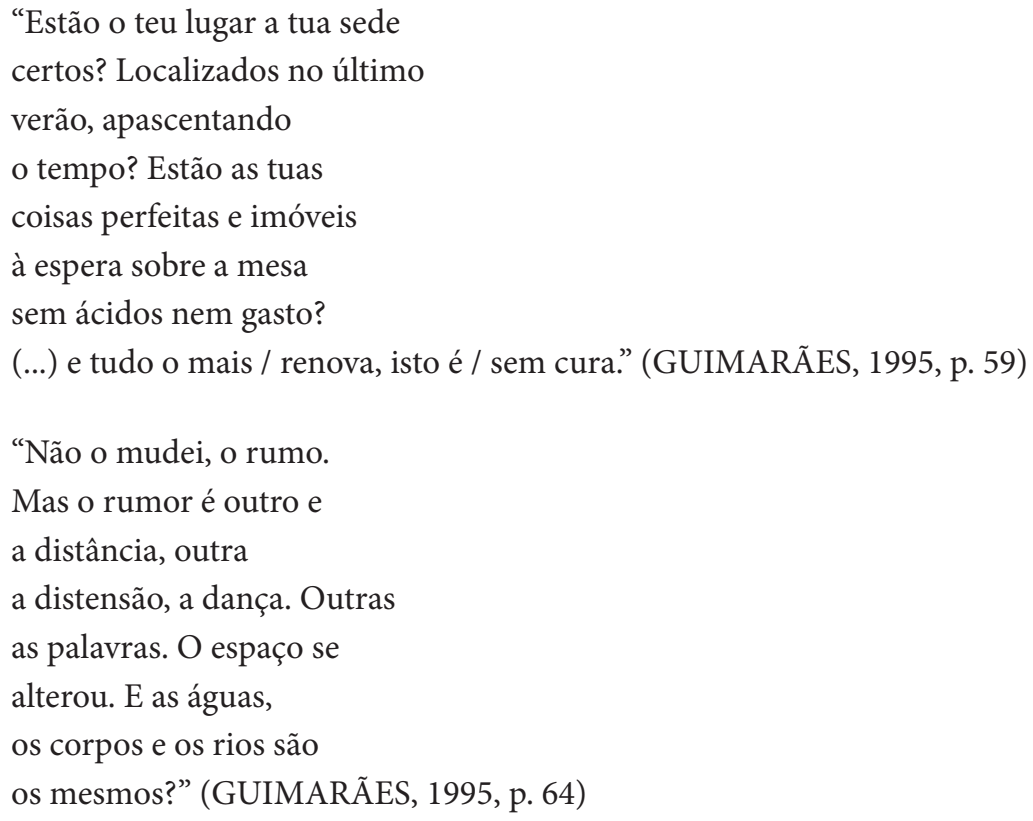

"Não o mudei, o rumo.

Mas o rumor é outro e

a distância, outra

a distensão, a dança. Outras

as palavras. O espaço se

alterou. E as águas,

os corpos e os rios são

os mesmos?” (GUIMARÃES, 1995, p. 64) 